Neda Necić1234

Faculty of Philosophy, University of Niš, Serbia
UDK 659.4:17

DOI https://doi.org/10.46630/msae.2.2021.07

Review article

\title{
ETHICS IN PUBLIC RELATIONS: ETHICAL THEORIES, CODES AND CONFLICTS
}

\begin{abstract}
Public relations, an important element of the media society, is a management function which helps establish and nurture the links of mutual communication, understanding, acceptance and cooperation between the organization and the surrounding public. The development of the public relations profession is commonly seen as a progressive evolution from unsophisticated and unethical early practice to the planned, strategic, ethical campaigns of the modern age. However, when discussing the practice of public relations in the XXI century, there are certain doubts, or rather, ethical conflicts. Being the key moral principle and the fundamental philosophical concept, truth should be the goal of every relationship and communication. However, in the public relations practice, truth is occasionally suppressed due to its partial placement. The process of communication itself functions to a significant extent through the mass media, and the violation of ethics in that respect is the trade in media space, which is a difficult form of violation of the philosophy of morality. The main purpose of this paper is to provide an overview of ethics and its development in public relations. This paper analyzes the ethics of public relations as a self-regulation platform for this profession. The application of ethical theories based on utilitarian and deontological approaches has also been discussed. In addition, codes of ethics applied in the PR profession are presented, as well as examples of unethical actions in the public relations profession.
\end{abstract}

Key words (bold): public relations, ethics, morality, codes, ethical conflicts

\section{Introduction}

More than a century ago, a group of pioneers began what we now call public relations. Today, public relations is recognized and accepted around the world; it is seen as an important part of management and a useful contribution to the successful

\footnotetext{
${ }^{1}$ This study was supported by the Ministry of Education, Science and Technological Development of the Republic of Serbia (Contract No. 451-03-9/2021-14/200165).

${ }^{2}$ This paper was presented at the Regional Conference "30 years of higher education in journalism and communication in Eastern Europe after 1989: From conquering the freedom of expression to embracing digital communication", which was held on 21 May 2021 (online conference).

${ }^{3}$ Received June 2021 / Accepted August 2021

${ }^{4}$ e-mail: neda.necic@filfak.ni.ac.rs
} 
operation and profitability of companies of all kinds. Many believe that the best way public relations activities serve an organization is when they act as its ethical conscience (Voza, Vuković, Riznić, 2009; Black, 2003).

Early public relations practice introduced many ethical problems as the media approach at the time emphasized hyperbole, sensationalism and the frequent absence of truth. There were also concerns as they sought to create publicity at all costs. All of this undoubtedly influenced the unethical reputation of public relations today (Bowen, 2007). It is also widely believed that the profession and the public relations industry itself cannot be ethical in any way, moreover, the term "ethics in public relations" is perceived as an oxymoron.

Similar to other developing professions, the public relations practice shows progress throughout its historical development towards more self-aware and ethical models of communication. If we observe the "evolution" of public relations, we can notice the maturing of the profession from the one that dealt with the simple dissemination of information to the profession involved in creating ethical communication. However, despite the steps taken and the efforts to make modern public relations ethically correct, this sphere still has a "lackened history", as described by Parsons (Parsons, 2004: 5). As Wright describes, ethics requires personal engagement, the search for best practice, understanding the rational decisions to be made and a good understanding of the consequences. Ethics cannot be enacted by legislation, it comes from within and is nurtured by life experiences and the standards and codes of conduct that are followed (Wright, 1993).

The main purpose of this paper is to provide an overview of ethics and its development in public relations. This paper analyzes the ethics of public relations as a platform for self-regulation of this profession. The application of ethical theories based on utilitarian and deontological approaches was also discussed. In addition, codes of ethics applied in the PR profession are presented. However, when it comes to discussing the practice of public relations, certain doubts arise, particularly ethical conflicts. The process of communication functions to a significant extent through the mass media and the violation of ethics in that respect is the trade in media space, which is a difficult form of violation of the philosophy of morality.

\section{Determining the concept of public relations and their function}

The term public relations was used in 1882 for the first time (Grunig, Hunt, 1984: 14). The Greek philosopher Socrates insisted on the correct definition of words before their use and believed that such definitions would remove possible misunderstandings. Therefore, it would be useful to define the term public relations by using the keyword method. If the word relations is understood as reciprocity or connection of individuals, objects or concepts, then it is clear that it relates to communication. Another word in the concept is public, which is the totality of the informed and knowledgeable individuals that form a general opinion. Based on these keywords, public relations denote communication between the organization and its public (Tomić, 2016). 
There are numerous definitions by PR practitioners, scientists and professional organizations in the literature. Rex F. Harlow has sublimated almost 500 definitions written between 1900 and 1976 and determined the main elements in each of them, aiming to explain what public relations are, not what they do. His definition has united both theoretical and practical elements: "Public relations are a distinctive management function that helps and cares for the relationships of mutual communication, understanding, acceptance and cooperation between the organization and its surrounding public; they also include managing of problems, help the management to be familiar with the public opinion and to react timely; they define and emphasize the responsibility of the management in the service of public interest, and they serve as an "early alarm system", by helping the management through their prediction of changes and using them effectively. For all of that they use research as its basic tool, as well as wise and ethical communication" (Harlow, 1976: 36).

Cutlip, Center and Broom define public relations as a "management function, whose aim is to establish and nurture mutually beneficial links between the organization and the different public, and the success or failure of the mentioned organization depends on them" (Cutlip, Center and Broom, 2006: 11).

The British Institute defined the role of public relations as an effort to establish and cherish "mutual understanding between an organization and its public" (Cutlip, Center and Broom, 2006: 8).

In the book Today's Public Relations - An Introduction (2006), R. L. Heath and W. T. Coombs state and define five public relations functions. They are: strategic planning, research, publicity, promotion and decision-making through cooperation. Upon closer inspection of the listed functions, it can be concluded that each individual function helps to build mutual understanding needed in the development of relationships between individuals, groups or institutions and they all help an individual or organization (Heath, Coombs, 2006).

\section{Historical overview of public relations}

Modern public relations activities have their roots in the distant past. Persuasion of the public in order to change attitudes and behavior, as a segment of public relations, can be found in the practices of ancient Sumerians, Assyrians, Persians and Egyptians. The technique of persuasion was developed in both ancient Greece and ancient Rome. The historical development of public relations techniques was described by Edward Bernays in his book Public Relations. Bernays considers the period of the French Revolution important, considering that the term "public opinion" came into use in Europe and both Americas. At that time, the Declaration of Human Rights publicly proclaimed the right to free expression of thought as one of the most important principles. Public relations was one of the most effective tools of the French Revolution, since books, pamphlets, newspapers, the stage, satire, hairstyles, and military insignia were used to shape public opinion (Black, 2003). 
Although the roots of public relations go back to the ancient past, the modern practice of public relations dates back to the beginning of the 20th century. It is a developing profession today and one of the management functions in organizations. This profession experiences changes and struggles through time in search of its own identity. It is considered that the term public relations was first used in the United States, consequently spreading to other countries (Tomić, 2016, Black, 2003; Broom, Sha, 2012; Bowen, 2007).

Cutlip, Center and Broom (2006) cite seven main periods in the development of public relations, and note that the dividing lines are blurred: the initial period (1900-1917), World War I (1917-1918), the twenties, the era of the rise (19191929), the era of Roosevelt and World War II (1930-1945), the post-war era (19461965), the period of protest and authorization (1965-1985) and the Digital Age and Globalization (1986 to the present) (Cutlip, Center and Broom, 2006).

The development of the public relations profession is usually seen as a progressive evolution of "unsophisticated unethical early practices to planning, strategic ethical campaigns of modern times" (Lamme, Russell, 2009: 281). Hoy and associates speak of the development of public relations as of progressive evolution "from a manipulative to a two-way, dialogic communication process" (Hoy et al., 2007: 191). Edward Bernays was identified as the main bearer of this historic perspective of public relations and he proposed three phases of public relations development that coincided with the historical development of the USA. The first phase started after the civil war and lasted until 1900 . He called it "the public bedamned-era". The second phase started from the beginning of the 20th century and the beginning of Public Relations, when the country entered the "public-beinformed-era". The period after the First World War marked the third phase as an era of "mutual understanding", when the knowledge of behavioral sciences was applied to public relations practice (Hoy et al., 2007; Broom, Sha, 2012). There was a change in the late 1960s. Various movements such as anti-war, consumer protection, human rights, environmental activism and other indicators of the increasing civil power growth and rights - including minorities - were a challenge for the existing status quo. Those who demanded changes were no longer satisfied with the fact that there was an understanding for their views, but required factual changes. This paradigm shift in society affected the change in public relations at the end of the 20th century, as well as later in the XXI century (Broom, Sha, 2012; Grunig, Hunt, 1984).

Lamme and Russell state three equivalent phases of the public relations development, and these are: representations in the press (press agentry), which was based on the principle of public deception; the publicity, according to which the public needs to be informed, decisively influenced by the work of Ivy Lee in the USA; and an advisory phase based on public understanding (Lamme, Russell, 2009: 287).

Based on these periods, James Grunig and Todd Hunt (1984) generated a synthetic-analytic model of the public relations development and left a far-reaching impact on the development of PR theory. Although it was the generalization of the already established public relations periods, this model became a dominant paradigm 
in the scientific sphere of this area (Lamme, Russell, 2009; Tomić, 2016). They integrated the modern development of public relations into four historical models, also the current public relations models:

1. The Publicity Model (1850 - 1900) in which attracting public attention was subordinated to the demands of truth in communication;

2. The Public Information Model (1900 - 1920) during which the principle of true information was rising as a reaction to publishing scandalous information on famous people obtained in a dishonest manner. It was a time when Ivy L. Lee appeared and he pointed out the importance of speaking the truth. Lee developed a publicity policy known as "Let the public be informed", so that the policy "Let the public be damned" was replaced.

3. The Two-Way Asymmetric Model (1920 - 1960) marked the public opinion-based communication strategies. Their results were used to optimize the process of persuasion and obtain public consent, i.e., produce the mass consent;

4. The Two-Way Symmetric model(1960-) emphasizes mutual understanding between communicators and audiences, in terms of communication rather than persuasion. Therefore, this model is more ethical and more efficient in public relations practice. Unlike the third asymmetric model, the feedback is strongly emphasized, with two-way communication. The role of PR in this model is the role of a mediator between an organization and the public. With the development of this model, modern public relations begin (Grunig, Hunt, 1984; Tomić, 2016).

\section{Theoretical foundations of ethics in public relations}

In order to better understand business ethics and other principles, it is important to point out the meaning of the terms ethics and morality. In recent years, these two concepts have been intertwined to such an extent that they cannot be distinguished; due to their similarity, they are often used as synonyms. This is not necessarily a bad thing, since professional ethical behavior cannot be completely separated from the general moral standards of society.

The term ethics is derived from the Greek word ethos, which means custom, use or character. Day defines ethics as a branch of philosophy that deals with the moral component of human life and is usually called the philosophy of morality (Day, 2004). Ethics refers to the formal study and codification of moral principles into certain normative frameworks. Based on this, decisions about what is right or wrong can be made in a rational, structured and reasoned way (Day, 2004; Juka, 2006; Tench, Yeomans, 2006; Gregory, 2006).

The term morality is derived from the Latin word mos, moris, which means a way of life or behavior, often associated with religious beliefs and personal behavior. Morality is a concrete form of human behavior that derives from human freedom and 
it is regulated by certain written or unwritten codes. Simply put, morality is made up of our personal values and principles (Day, 2004; Juka, 2006; Tench, Yeomans, 2006; Gregory 2006).

Cutlip, Center and Broom cite utilitarianism and deontology as two approaches to the philosophy of morality in ethical decision-making. Although they use different approaches, both utilitarianism and deontology help with public relations, assessment and advice related to making ethically correct decisions in an organization (Cutlip, Center and Broom, 2006: 138). Grunig, Grunig and Dozier also propose consequential and non-consequential theories in ethical decision-making in public relations (Grunig, 2014).

\subsection{Utilitarian philosophy and the consequential ethical concept of public relations}

Consequential theories focus on the consequences of behavior. This approach is known as teleological and the most well-known consequential theory is utilitarian (Tench, Yeomans, 2006). Utilitarian philosophy or utilitarianism is based on the principles set by English philosophers Jeremy Bentham and John Stuart Mill. Utilitarianism takes into account the usefulness, that is, the expected result or effect of a certain decision in order to determine what is right. Therefore, ethically correct moves should bring the greatest possible amount of benefit to the greatest possible number of people. The utilitarian approach in ethical decision-making should maximize the benefits of society and reduce harm, i.e., the overall balance of good consequences over bad is important (Tench, Yeomans, 2006; Cutlip, Center and Broom, 2006; Juka 2006; Trevino, Nelson, 1995).

Utilitarianism is also important in the ethics of public relations, so public relations experts must take this principle into account when making ethical decisions. "In order to determine how moral an act is, as seen from a utilitarian perspective, a PR expert must take into account all alternative decisions and determine which option brings favorable outcomes to the largest number of people. The best option will be chosen by the overall positive effects and the minimal negative consequences" (Cutlip, Center and Broom, 2006: 138).

Some authors state that the classical understanding of utilitarianism has several problems that limit its usefulness: utilitarianism can be used to maintain a status quo in which the majority is happy but not all. Therefore, the interests of marginal groups are neglected, i.e., some groups are always privileged (Cutlip, Center and Broom, 2006; Kurtić, 2009). Another problem is that it is difficult to arrive at facts on the basis of which consequences can be predicted - that is, many consequences cannot be predicted and thus create the possibility of serious and costly erroneous calculations during a utilitarian analysis; (Juka, 2006). The third problem is that utilitarianism implies that the goal justifies the means (Kurtić, 2009; Tench, Yeomans, 2006; Cutlip, Center and Broom, 2006). 


\subsection{Deontological philosophy and the non-consequential ethical concept of public relations}

Acting on a certain principle and a motive, with universal moral values and regardless of the nature of the consequences of these actions, forms the core of dutybased theories. These are deontological, i.e., non-consequential theories. The most famous deontologist was the German philosopher Immanuel Kant and his theories are called duty-based moral philosophy. This means the obligation to tell the truth, regardless of whether we will hurt others (Day, 2004; Juka, 2006; Cutlip, Center and Broom, 2006; Tench, Yeomans, 2006). In deontology, the ethical value of an action does not depend on its outcome, since predicting accurate outcomes is beyond human capabilities and control (Cutlip, Center and Broom, 2006). Kant points out that being truthful out of duty is very different from doing so out of one's concern related to harmful consequences. He defined universal principles of morality based on a categorical imperative, which he defines as a "moral law that is directly within us as an a priori requirement of our mind, which it sets by its structure to will or intention" (Juka, 2006: 189). Since they emphasize the commitment to rules, duties, they are also called absolutists, because they do not recognize exceptions (Day, 2004).

Both the United Nations Declaration, the Universal Declaration of Human Rights and the American Declaration of Independence uphold deontological principles by guaranteeing the individual rights that should not be violated, such as the right to life, liberty, security and equality before the law. It is the duty of society and individuals to preserve these rights (Tench, Yeomans, 2006).

Tench and Yeomans list three main problems with deontological decisionmaking. The first problem is what will happen if two good moral principles clash; another problem is fulfilling a moral obligation regardless of the consequences; the third problem is that moral principles are not universal, and differ from society to society (Tench, Yeomans, 2006).

Najil Kurtić (2009) sees the solution to ethical challenges in returning to basic moral principles - do not lie, do not cheat and do not be dishonest. "The problem of lying, deception, insincerity and dishonesty is at the center of every ethical discourse, even the one about the ethics of public relations. Are there cases in which a corporation should lie? Consequentialists say: Yes, if it is a way to bring maximum happiness, that is, to avoid misfortune (to oneself or to the majority of one's public). Non-consequentialists say: Yes, if "lying" is a generally accepted principle, which the organization can accept in relation to itself. However, since the organization cannot function on the basis of misinformation and lies, the answer is NO. Do not lie under any circumstances. Fraud cannot be justified by any ultimate goals. A request that does not tolerate exceptions is decisive not to lie" (Kurtić, 2009: 133).

Some authors also cite the good sides of deontology: using a deontological approach in ethically controversial situations means that decisions are made based on what is good or bad and not based on the principle of who benefits the most. In this regard, the public relations expert may consider the positions of different stakeholders. Furthermore, the deontological approach allows public relations to 
advise management on what to do, but on the basis of moral principles and not on the basis of price and cost, personal interest or benefit. Another advantage of using a deontological approach in public relations is a more open approach to change through an open model of communication. Thus, the organization can respond to the pressures for change that come from the external environment, regardless of who is in the majority. This allows the minority to have as much influence on issues and problems as the majority (Cutlip, Center and Broom, 2006).

\section{Ethics and public relations}

The ethics of public relations deals with moral behavior of PR experts, as well as norms in which this behavior is framed and grounded. What the ethics of public relations specifically deals with is transparency, keeping secrets, truth, objectivity, precision, problems and limits of influence on politicians (lobbying) and journalists (Milas, 2012).

As public relations became further recognized as a profession, specialized associations and organizations were formed in parallel. Although these associations do not include all those who deal with public relations, they still exert their influence through the printing of publications and the organization of conferences and seminars. These organizations can be of national, international or regional character and are divided according to the narrower expertise of their members. Some of the international, national and regional PR organizations are as follows: Public Relations Society of America (PRSA), International Public Relations Association (IPRA), International Association of Business Communicators (IABC), Chartered Institute of Public Relations (CIPR), Global Alliance for Public Relations and Communication Management (GA), Public Relations Institute of Southern Africa (PRISA), British Institute of Public Relations (IPR), Public Relations Consultants Association (PRCA), Confederation of European Public Relations (CERP), Public Relations Institute of Australia (PRIA), Public Relations Agencies Association of Mexico (PRAA), Spanish Association of Communicators (DIRCOM), American Latina Public Relations (PRSK), Romanian Public Relations Association (RPRA) and the Public Relations Society of Kenya (PRSK) (Terek, 2016).

\subsection{Codes of ethics - instruments of self-regulation in public relations}

Due to the strong influence that public relations has on society, defining professional ethical rules is of paramount importance. National and international PR organizations, sometimes large PR agencies, define codes of ethics and ethical norms of conduct in the profession.

For more than 70 years, public relations and communications bodies have been establishing codes of ethics that help public relations and communications professionals detect, deter and condemn unethical behavior. Most professional 
public relations and communication bodies have their own codes of ethics and offer guidance to their members.

Here are some of the codes of ethics:

- Ivy Lee drafted the Declaration of Principles in 1906, which was the first code of ethics for public relations (Tomić, 2016);

- The International Code of Ethics, informally known as the Athens Code, was adopted by the General Assembly of the European Confederation of Public Relations. The Athens Code was adopted by the International Public Relations Association (IPRA) in Athens on May 11, 1965. This code was amended in 1968 and 2009. The Code is a moral charter of the IPRA Association, and the principles of the Code were inspired by the UN Universal Declaration of Human Rights. All member states of the United Nations have pledged to abide by the UN Charter. The Athens Code prohibits the subordination of truth to other requirements and the distribution of information from unreliable sources. In addition, it prohibits activities that do not respect morals, human dignity, privacy, as well as the use of methods and means for the purpose of manipulation ${ }^{5}$ (Mirosavljević, 2008; Tomić, 2016; Broom, Sha, 2012);

- The European Code of Professional Conduct in PR Practice (the so-called Lisbon Code) is one of the most well-known international codes. It was officially adopted at the General Assembly of CERP (Confederation of European Relations Public) in Lisbon on April 16, 1978, and amended on May 13, 1989. The Lisbon Code relies on the Athens Code and defines general rules of conduct as well as specific norms of behavior and nineteen points related to employers, public opinion and the media, colleagues but also to the entire profession. This Code obliges members to respect the principles of the Universal Declaration of Human Rights and Freedoms. Special emphasis is placed on respect for freedom of expression and freedom of the media, which ensure the right of the individual to seek and receive information ${ }^{6}$ (Mirosavljević, 2008; Tomić, 2016);

- In 2000, the Global Alliance published the guiding principles of the profession. The basis of this alliance is to develop a global standard in the form of a set of principles for ethical public relations practice. The General Assembly first adopted such a code in 2003, and updated it in $2018^{7}$ (Parsons, 2004);

- The Serbian Public Relations Association (DSOJ) was founded on May 17, 2004, continuing the tradition of the Yugoslav PR Association. The Company's Code of Professional Ethics is in line with the Athens Code and the Code of the International Public Relations Association. This code prescribes the conditions of behavior of members and their attitude towards service users. An annual award has been established which is awarded to members for the best results in the field of communications; ${ }^{8}$

\footnotetext{
${ }^{5}$ https://www.ipra.org/static/media/uploads/pdfs/ipra_code_of_athens.pdf (accessed April 23, 2021)

${ }^{6} \mathrm{http}: / /$ www.eccom.info/index.php/toolbox/code-of-ethics-public-relations/141-european-code-of-professionalconduct-in-public-relations (accessed April 23, 2021)

${ }^{7}$ https://www.globalalliancepr.org/code-of-ethics (accessed April 23, 2021)

${ }^{8}$ http://pr.org.rs/o-nama/misija-i-vizija (accessed April 25, 2021)
} 
- The Chartered Institute of Public Relations (CIPR) is the leading professional institution of the PR industry in the UK and the largest PR association in Europe. Members of the Chartered Institute of Public Relations (CIPR) have adopted a set of ethical principles, and have agreed to maintain the highest standard of professionalism ${ }^{9}$ (Broom, Sha, 2012; Parsons, 2004).

\subsection{Ethical conflicts in public relations}

The implementation of ethical principles in practice is the most important responsibility of any public figure and the code of ethics should serve as a motivation model to other organizations and activities. Non-compliance with the codes of ethics and norms inevitably leads to ethical conflicts.

An example of how non-compliance with the codes of ethics and norms of conduct leads to ethical conflicts occurred on December 9, 2008. The Croatian Public Relations Association reacted strongly to a statement issued by a mayor. It could be concluded from the statement that he, through a public relations agency, financially secured his position in the shows of the Croatian Public Broadcasting company. The Croatian Public Relations Association responded with the following statement: "The working methods stated in this case are not a legitimate way of doing business for CPRA members and therefore do not reflect the nature of the profession. CPRA strongly condemns any form of manipulation of the public media space, corruption and unprofessionalism; rather, it achieves relations with the media through long-term cooperation and partnership, which includes the use of transparent means of communication". In particular, the PR agency in question was not a member of CPRA; nevertheless, the reputation of the public relations profession has been damaged. In this example, the Croatian Public Relations Association showed its role in the development of the public relations profession, because they reacted to the problem that the profession encountered. ${ }^{10}$

A similar example of ethical conflict occurred in Germany, in June 2008. At that time, a marketing and PR agency paid the editor of a well-known print publication the amount of 500 euros for publishing an article about opening a private business space in Duisburg. Shortly afterwards, the German Public Relations Council issued a public reprimand to a person from the PR agency, explaining the bribery of the editorjournalist because the representative of the PR agency sharply violated the ethical principles of the PR profession. In doing so, they referred to Article 10 of the Lisbon Code, which reads: "News and information must be written free of charge and without hidden rewards, all for the purpose of public use and publication" (Milas, 2012).

Some PR companies aggravate various situations with their unethical behavior. Namely, one of the most notable examples was "Citizens for a Free Kuwait". It was a scheme of a PR agency to organize a pre-group called "Citizens for a Free Kuwait", in order to cover up the role of the Kuwaiti government in this effort. This company created a false

\footnotetext{
${ }^{9} \mathrm{https}: / /$ cipr.co.uk/CIPR/About_Us/Governance_CIPR_Code_of_Conduct.aspx (accessed April 25, 2021)

10 https://www.jutarnji.hr/naslovnica/hrt-i-huoj-kontakti-novinara-i-pr-ovaca-ne-smiju-biti-stihijski-3996222 (accessed April 28, 2021)
} 
statement and submitted it to the Congressional Committee on Human Rights. News later leaked that the Kuwaiti government sponsored this pre-group to persuade the United States to enter the Gulf War in 1992. Later, this campaign reached the media and the behavior of the PR company was severely criticized. After this controversy, the executive director of this PR company notoriously reminded the staff: "We would represent Satan if he paid"11.

The first two examples are similar in nature because both examples are about the bribery of journalists. In these examples, there were ethical conflicts between the public relations profession and journalism. Namely, the mentioned relationship between these two professions can be explained by a model of determinism and the model of interest. When it comes to the model of determinism, Baerns (1985) states that journalism as an autonomous organisation backed over to public relations presentations. According to the determinism model, public relations greatly control the themes and time of media reporting, but not journalism as a whole, as opposed to the interefication model. Thus, the mentioned models are subject to different things (Baerns, 1985). The interefication model, on the other hand, is based on the fact that each side merely ensures the result for the other side. To be exact, according to this model, PR and journalism are perceived as related in terms of mutual influence, orientation and addiction between two relatively autonomous systems. That is, this model considers the interaction between journalism and public relations and analyzes it as a relationship between two professions (Bentele, Liebert, Seeling, 1997).

These examples of ethics violation in public relations can also be seen as acceptance and guidance of an utilitarian model of ethical decision-making. Since in these examples the goal justified the means, the result proved to be unethical as the means in the examples were money and untrue information. Najil Kurtić (2009) sees the solution for ethical challenges in the restoration of basic moral principles - do not lie, do not cheat, do not be dishonest, do not be insincere. "The problem of lying, fraud, insincerity and dishonesty is at the center of any ethical discourse, and also of public relations. Are there cases where the corporation would be lying? Consequentialists say: Yes, if this is a way to bring maximum happiness, ie. avoid accidents (related to self or public). Non-consequentialists say: Yes, if the "lying" is a generally accepted principle, which organization can also accept in relation to itself. However, since the organization cannot function on misinformation and lies, the answer is NO. Do not lie in any circumstances. Fraud (lie) cannot justify any ultimate objectives. Do not lie, is a decisive request that does not have exceptions" (Kurtić, 2009: 133).

\section{Conclusion}

It is certain that there are still many examples of unethical behavior in public relations. The code itself means very little if it is not consistently implemented in practice. However, codes of ethics and norms are self-regulatory bodies within the profession, so there is no adequate sanction for non-compliance. Thus, although codes of ethics and professional

\footnotetext{
${ }^{11} \mathrm{https}: / /$ prboutiques.com/how-public-relations-ethics-violations-undermine-trust/ (accessed June 10, 2021)
} 
norms serve as evidence of the professional status of public relations, they are nevertheless voluntary in nature. Since PR is a developing profession, it still has shortcomings. What is also missing is the impossibility of detecting violations of ethical norms and codes, unlike journalism where violations of ethical norms and codes are more noticeable.

Some academic researchers criticize codes of ethics because they do not contribute to the realization of the ideals they advocate and because they believe that codes of ethics are often too general to be used in their practices (Parkinson, 2001; Wright, 1993). Although codes of ethics and professional norms validate the professional status of public relations, their implementation is difficult as they pose no threat and have no consequences. One of the key shortcomings is that most codes of ethics neither ensure the enforcement of provisions nor an adequate procedure in case of violation of the code which makes them inefficient; the only result can be the revocation of membership in the association (Cutlip, Center and Broom, 2006; Bowen, 2007).

On the other hand, some theorists are of the opinion that if PRs are ethical, then there is no need to impose codes of ethics (Kruckeberg, 2000), while others believe that a simple ethical statement is all that is needed because good intention is a much more rigorous guide than a code of ethics (Bowen, 2007; Parkinson, 2001). As Parsons illustrates: "Good people do not need laws to tell them to act responsibly, while bad people will always find a way to circumvent the laws" (Parsons, 2004: 67).

\section{References}

Baerns, B.(1985). Öffentlichkeitsarbeitoder Journalismus? Zum Einfluss im Mediensystem, Verlag Wissenschaft und Politik, Köln.

Bentele, G., Liebert, T. und Seeling, S. (1997). Von der Determination zur Intereffikation. Ein integriertes Modell zum Verhältnis von Public Relations und Journalismus, in: Bentele, G. und Haller, M. Aktuelle Entstehung von Öffentlichkeit. Akteure, Strukturen, Veränderungen (pp. 225-250)

Blek, S. [Black, S.] (2003). Odnosi s javnošću - drugo izdanje. Beograd: Clio.

Bowen, S. A. (2007). "Ethics and Public Relations". The Institute for Public Relations. URL:https://media.gradebuddy.com/documents/1844913/1ef67220-c1e3-407d-8c51b46ef029flcd.pdf

Broom, M. G, Sha, B. (2012). Cutlip and Center's effective public relations - eleventh edition. Pearson.

Katlip, S., Senter, A., Brum, G. [Cutlip, S., Center, A., Broom, G.] (2006). Uspešni odnosi s javnošću. Beograd: Službeni glasnik.

Dej, L. A. [Day, L. A.] (2004). Etika u medijima-primeri i kontroverze. Beograd: Medija centar.

Gregory, A. (2006). Planning and Managing Public Relations Campaigns. Kogan Page.

Grunig, J., Hunt, T. (1984). Managing Public Relations. Holt/Rinehart \& Winson, New York-Chicago.

Grunig, J. (2014). "Ethics problems and theories in public relations" Communiquer, 11, 1-14. URL: https://journals.openedition.org/communiquer/559 
Harlow, F. Rex (1976). "Building a Public Relations Definition”, Public Relations Review 2, br. 4, str. 36 URL: https://www.sciencedirect.com/science/article/abs/pii/ S0363811176800227

Heath, R., Coombs, T. (2006). Today`s Public Relations-An Introduction. Sage Pub., Thousand Oaks.

Hoy, P., Raaz, O. \& Wehmeier, S. (2007). "From Facts to Stories or from Stories to Facts? Analyzing Public Relations History in Public Relations Textbooks". Public Relations Review, 33(2): 191-200. DOI: 10.1016/j.pubrev.2006.11.011

Juka, S. (2006). Etika - postavke i teorije. Mostar: Fram-Ziral.

Kruckeberg, D. (2000). “Thepublic relations practitioner's role in practicing strategic ethics". Public Relations Quarterly, 45(3), pp. 35-40. URL:https://www.proquest.com/openv iew/3cacad4f41784d824aaf360e668909ca/1?pq-origsite=gscholar\&cbl=49209

Kurtić, N. (2009). "Etički odnosi s javnostima u funkciji socijalne konekcije i društvene odgovornosti modernih organizacija”. MEDIANALI, 3 (5), pp. 131- 142, URL: https://hrcak.srce.hr/39295

Lamme, M. O. \& Russell, K. M. (2009). "Removing the Spin: Toward a New Theory of Public Relations History". Journalism \& Communication Monographs, 11(4): 280-362. URL:http://citeseerx.ist.psu.edu/viewdoc/download?doi=10.1.1.857.2582\&rep $=$ rep $1 \&$ type $=$ pdf

Milas, D. (2012). “Etički konflikti u odnosima s javnošću”. MEDIANALI, Vol. 6 (2012), No. 11, pp. 51-66. URL:https://hrcak.srce.hr/109158.

Mirosavljević, M. (2008). Odnosi s javnošću. Banja Luka College - Besjeda Banja Luka, Banja Luka.

Parkinson, M. (2001). “The PRSA code of professional standards and member code of ethics: Why they are neither professional nor ethical". Public Relations Quarterly, Fall, pp. 27- 31, URL:https://www.proquest.com/openview/8924bcbad3d6b70ebbb 1a6b7d55f1c06/1?pq-origsite $=$ gscholar\&cbl=49209

Parsons, P. J. (2004). Ethics in Public Relations: A Guide to Best Practice. London and Philadelphia: Kogan Page Limited.

Tench, R., Yeomans, L. (2006). Exploring Public Relations, Pearson.

Terek, E. (2016). Uticaj odnosa s medijima na pojedine organizacione i poslovne performanse u preduzećima u Srbiji - doktorska disertacija. Univerzitet u Novom Sadu, tehnički fakultet Mihajlo Pupin, Zrenjanin, URL:https://nardus.mpn.gov.rs/ bitstream/id/33207/Disertacija13349.pdf

Tomić, Z. (2016) Odnosi s javnošću - teorija i praksa, drugo dopunjeno i izmenjeno izdanje. Zagreb, Sinopsis

Trevino, L. K., Nelson, K. A., (1995). Managing Business Ethics: Straight talk about how to do it right. New York: Wiley and Sons.

Voza, D., Vuković, M., Riznić, D. (2009). "Etički aspekti u odnosima s javnošću”. Marketing: časopis za marketing teoriju i praksu. Vol 40. Broj 4, pp. 233-240. URL: http://www.sema.rs/repository/download/marketing-vol-40-no-4.pdf

Wright, D. K. (1993). "Enforcement dilemma: Voluntary nature of public relations codes". Public Relations Review, 19(1), pp. 13-20, URL:https://www.sciencedirect.com/ science/article/abs/pii/0363811193900269 


\section{Website}

New World Encyclopedia https://www.newworldencyclopedia.org/entry/Ivy_Lee (accessed April 20, 2021)

International Public Relations Association https://www.ipra.org/ (accessed April 23, 2021)

Global Alliance https://www.globalalliancepr.org (accessed April 23, 2021)

Društvo Srbije za odnose s javnošću http://pr.org.rs/ (accessed April 25, 2021)

The Chartered Institute of Public Relations- CIPR https:/www.cipr.co.uk/ (accessed April 25, 2021)

Jutarnji hr (29 December 2008) https://www.jutarnji.hr/naslovnica/hrt-i-huoj-kontaktinovinara-i-pr-ovaca-ne-smiju-biti-stihijski-3996222 (accessed April 28, 2021)

Lucy Siegel (29 July 2020) https://prboutiques.com/how-public-relations-ethics-violationsundermine-trust/ (accessed June 10, 2021)

\section{ETIKA U ODNOSIMA S JAVNOŠĆU: ETIČKE TEORIJE, KODEKSI I KONFLIKTI}

Apstrakt. Odnosi s javnošću, kao važan element medijskog društva, predstavljaju funkciju upravljanja, koja pomaže da se uspostave i neguju veze uzajamne komunikacije, razumevanja, prihvatanja i saradnje između organizacije i javnosti koje je okružuju. Razvoj profesije odnosa s javnošću se uobičajeno posmatra kao progresivna evolucija od nesofisticirane $i$ neetičke rane prakse do planskih, strateških etičkih kampanja savremenog doba. Međutim, kada je reč o raspravi o praksi odnosa sa javnošću i u XXI veku, javljaju se određene nedoumice, tačnije etički sukobi. Istina kao vrhovni moralni princip i temeljni filozofski pojam bi trebalo da bude cilj svakog odnosa $i$ komunikacije. U praksi odnosa s javnošću se dešava da istina biva povređena, usled njenog delimičnog plasiranja. Sam proces komunikacije u značajnoj meri funkcioniše posredstvom masovnih medija, a kršenje etike u tom pogledu je trgovina medijskim prostorom, što je težak oblik kršenja filozofije morala. Glavna svrha ovog rada je da pruži pregled etike i njenog razvoja u odnosima s javnošću. U ovom radu je analizirana etika odnosa sa javnošću kao platforma za samoregulaciju ove profesije. Takođe je diskutovano o primeni etičkih teorija zasnovanih na utilitarnim i deontološkim pristupima. Pored toga, predstavljeni su etički kodeksi koji se primenjuju u PR profesiji, ali i primeri neetičkog delovanja u profesiji odnosa s javnošću.

Ključne reči: odnosi s javnošću, etika, moral, kodeksi, etički konflikti 